\title{
PROSES KREATIF DEE LESTARI DALAM MENULIS SERIAL SUPERNOVA (KAJIAN EKSPRESIF)
}

\author{
Rahayu Dwi Rahmawati \\ Pendidikan Bahasa dan Sastra Indonesia, PPs Universitas Negeri Yogyakarta \\ email: rahayud56@gmail.com
}

\begin{abstract}
ABSTRAK
Penelitian ini bertujuan untuk mengetahui (1) proses kreatif Dee Lestari dalam menulis serial Supernova, (2) faktor-faktor yang memengaruhi Dee Lestari dalam menulis serial Supernova, (3) wujud proses kreatif Dee Lestari dalam menulis serial Supernova, dan (4) teknik penceritaan Dee Lestari dalam menulis serial Supernova. Penelitian ini merupakan penelitian kualitatif deskriptif. Sumber data berupa wawancara dengan narasumber dan novel serial Supernova. Pengumpulan data dilakukan dengan teknik baca catat dan wawancara. Analisis data menggunakan deskriptif kualitatif yang terdiri atas memilih data, mereduksi data, menyajikan data, dan menarik kesimpulan. Hasil penelitian ini menunjukkan bahwa tahapan proses kreatif Dee Lestari terbagi menjadi empat tahapan yakni tahapan persiapan, inkubasi, iluminasi dan verifikasi. Faktor-faktor yang memengaruhi proses kreatif terbagi atas faktor internal terdiri atas suasana hati, pengalaman hidup, imajinasi dan intuisi. Sementara faktor eksternal terdiri atas jenis kelamin, umur, pandangan hidup, latar belakang sosial dan budaya serta dorongan menulis. Wujud proses kreatif dalam menulis serial Supernova terdiri atas empat elemen yakni tema, alur, latar, dan penokohan. Teknik penceritaan dalam menulis serial Supernova terbagi atas lima teknik, yakni teknik pemandangan, adegan, montase, kolase, dan asosiasi.
\end{abstract}

Kata Kunci: proses kreatif, pengarang, kajian ekspresif, serial Supernova

\section{CREATIVE PROCESS OF DEE LESTARI IN WRITING SUPERNOVA SERIES (AN EXPRESSIVE STUDY)}

\begin{abstract}
This study aims to reveal (1) Dee Lestari's creative process in writing the Supernova series, (2) the factors that influence Dee Lestari in writing the Supernova series, (3) the creative process of Dee Lestari in writing the Supernova series, and (4) the technique telling Dee Lestari in writing the Supernova series. This research is descriptive qualitative research. The sources of data in this study were interviews with resource persons and serial novels Supernova. Data collection was done by reading note technique and interview. Data analysis in this study used qualitative descriptive consisting of selecting data, reducing data, presenting data, and drawing conclusions. The results of this study indicate that the stage of the creative process Dee Lestari was divided into four stages of preparation stage, incubation stage, illumination stage and verification stage. Factors that affect Dee Lestari's creative process are divided into internal factors comprising mood, life experience, imagination and intuition, while external factors consist of gender, age, life view, social and cultural background and writing impulse. The creative process of Dee Lestari in writing the Supernova series consists of four elements, namely theme, plot, background, and characterization. Dee Lestari's storytelling technique in writing the Supernova series is divided into five techniques, namely scenery, scene, montage, collage, and association techniques.
\end{abstract}

Keywords: creative process, author, expressive study, Supernova series 


\section{PENDAHULUAN}

Sastra lahir oleh dorongan manusia untuk mengungkapkan diri, tentang manusia, kemanusiaan, dan semesta. Sastra sebagai sebuah karya seni, juga sebagai karya kreatif yang dimanfaatkan sebagai konsumsi intelektual dan emosional. Sastra yang telah dilahirkan oleh pengarang diharapkan dapat memberikan kepuasan estetik dan intelektual bagi pembaca. Namun, seringkali karya sastra tidak dapat dinikmati dan dipahami secara utuh oleh pembacanya. Pemahaman terhadap karya sastra akan semakin baik jika disertai pemahaman tentang pengarangnya.

Dalam hal ini perlu adanya penelaah dan peneliti sastra (Semi, 1993: 1). Studi sastra memerlukan penjelasan mengenai kepribadian dan kehidupan sastra. Kepribadian dan kehidupan pengarang dapat dipahami antara lain melalui biografi pengarang. Biografi pengarang bernilai jika biografi itu berisi hal-hal yang berkaitan dengan penciptaan karya sastra. Antara pengarang dan karya sastranya memiliki hubungan yang erat. Hubungan itu dapat berupa kesejajaran dan kebalikan. Dikatakan hubungan kesejajaran jika apa yang ada di dalam kepribadian dan kehidupan pengarang tercermin dalam karya sastranya. Dikatakan hubungan kebalikan jika apa yang ada di dalam karya sastranya merupakan sesuatu yang digunakan untuk menyembunyikan kepribadian pengarang yang sesungguhnya.

Salah satu pengarang Indonesia yang karya-karyanya selalu dinantikan adalah Dewi Lestari atau yang biasa dikenal dengan nama pena Dee Lestari. Dee Lestari terkenal dengan kepiawaiannya dalam merangkai kata menjadi cerita yang bermakna, seperti dalam novel serialnya Supernova, yang ia jejalkan dengan ramuan pengetahuan sains, percikan filsafat, spiritualitas, dan berbagai mitos.

Pada tahun 2000, Dee Lestari menulis sebuah manuskrip yang ia rasa layak menjadi buku pertamanya, yakni Supernova: Kesatria, Putri, dan Bintang Jatuh (KPBJ). Pada bulan Januari 2001, Supernova: KPBJ terbit, dan di luar dugaan memecahkan rekor buku terlaris dalam waktu singkat. Tujuh ribu buku habis terjual dalam waktu empat belas hari. Setelah terbitnya Supernova: KPBJ, Dee Lestari mulai dikenal sebagai penulis. Aktivitasnya sebagai penyanyi terus berkurang, hingga pada tahun 2003 akhirnya ia keluar dari grup vokal Rida Sita Dewi (RSD). Episode kedua Supernova: Akar menyusul pada tahun 2002, lalu Supernova: Petir pada tahun 2004.

Delapan tahun kemudian, episode $\mathrm{Su}$ pernova kembali terbit pada tahun 2012 dengan judul Supernova: Partikel. Partikel mendapat ulasan positif dari kritikus sastra. Bahkan, Goenawan Mohamad membuat satu Catatan Pinggir dengan judul Zarah, yang merupakan tokoh utama dalam Partikel. Episode kelima Supernova: Gelombang terbit pada bulan Oktober 2014. Pada Anugerah Pembaca Indonesia 2015, Dee Lestari dan Gelombang berhasil meraih predikat Penulis Fiksi Favorit Pembaca dan Buku Fiksi Favorit Pembaca. Episode terakhir Supernova yakni Intelegensi Embun Pagi mendapat predikat Book of The Year dalam penghargaan IKAPI pada tahun 2016.

Pemilihan Dee Lestari sebagai objek kajian penelitian dalam memahami proses kreatif pengarang tidak terlepas dari hubungan pengarang dalam menghasilkan sebuah karya yang bernilai. Mahayana (2007: 89) menelaah karya Dee Lestari yang terkait di awal abad ke21. Menurutnya, Dee Lestari melalui Supernova berhasil menawarkan mainstream baru dalam peta novel Indonesia, dengan memasukkan deskripsi ilmiah sebagai bagian integral dalam cerita.

Karya sastra sebagai salah satu karya budaya merupakan tanggapan sastrawan terhadap lingkunganya. Kemudian, sastrawan mewujudkannya secara estetis dan memiliki nilai keindahan. Oleh karena itu, kelahiran karya sastra selalu memiliki nilai guna bagi masyarakat (Mabruri, 2015: 104). Junus (1985: 1-2) menyatakan bahwa untuk memahami suatu karya sastra yang sesuai dengan hakikat karya sastra yang polisemi, maka ada suatu "keinginan" untuk menemui "arti yang sebenarnya". "Arti" tersebut dapat ditemukan dengan menghubungkan karya sastra tersebut dengan pengarangnya. Berdasarkan pendapat Junus tersebut dapat diketahui bahwa pengarang memiliki kedudukan yang penting dalam menafsirkan sebuah karya sastra. 
Berdasarkan uraian di atas, penelitian ini akan mendeskripsikan Proses Kreatif Dewi Lestari dalam Menulis serial Supernova: Kajian Ekspresif. Penelitian mengenai proses kreatif Dee Lestari, belum pernah dilakukan sebelumnya. Diharapkan, dengan adanya penelitian ini dapat menambah khazanah pengembangan ilmu sastra khususnya mengenai proses kreatif seorang pengarang. Penelitian ini juga menggunakan pendekatan ekspresif, yang dikemukakan oleh Abrams (1971: 22) sebagai penelitian karya sastra yang menekankan peranan penulis karya sastra sebagai penciptanya. Pendekatan ini memandang karya sastra sebagai pernyataan dunia batin pengarang yang bersangkutan. Jika dibayangkan bahwa segala gagasan, cita rasa, emosi, ide, dan angan-angan merupakan 'dunia dalam' pengarang, karya sastra merupakan 'dunia luar' yang bersesuaian dengan 'dunia dalam' itu, dengan cara pendekatan ini, penilaian karya sastra tertuju pada emosi atau keadaan jiwa pengarang.

\section{METODE}

Jenis penelitian yang relevan terhadap proses kreatif Dee Lestari adalah penelitian kualitatif dengan metode deskriptif kualitatif. Setting penelitian menyesuaikan dengan teknik pengumpulan dan analisis data. Subjek penelitian adalah proses kreatif Dee Lestari dengan unit analisis berupa pernyataan yang menggambarkan tahapan proses kreatif dan faktor-faktor yang memengaruhi proses kreatif dalam menulis serial Supernova, serta kata-kata ataupun kalimat yang menggambarkan wujud proses kreatif dan teknik penceritaan. Sumber data primer adalah hasil wawancara serta tanya jawab berbagai seminar yang menghadirkan Dee Lestari sebagai narasumber, hasil wawancara dengan editor Supernova, dan novel serial Supernova. Sumber data sekunder didapatkan dari buku-buku, artikel dalam jurnal, dan penelitian terdahulu yang relevan dengan penelitian ini. Penelitian ini mengumpulkan data dengan dua macam cara, yakni teknik baca catat dan wawancara. Teknik analisis data dalam penelitian ini mencakup empat kegiatan yaitu pengumpulan data, reduksi data, penyajian data, dan penarikan kesimpulan.

\section{HASIL DAN PEMBAHASAN \\ Tahapan Proses Kreatif Dee Lestari dalam Menulis Serial Supernova}

Proses kreatif seorang pengarang memiliki perbedaan antara satu dan yang lainnya. Proses kreatif dalam hal ini lebih dimaksudkan sebagai cara atau teknik bagaimana seorang pengarang mulai menulis dan menyelesaikan karyanya. Tahapan proses kreatif Dee Lestari sejak awal penulisan hingga akhir melalui empat tahap yakni tahapan persiapan, tahapan inkubasi, tahapan iluminasi, dan tahapan verifikasi. Tahapan persiapan bagi seorang pengarang dimulai ketika berbagai ide awal diakumulasikan dengan berbagai ide lain sehingga muncul ide utama yang mendorong pengarang untuk menghasilkan sebuah karya sastra (Jabrohim, dkk, 2003: 79). Ide awal menulis serial Supernova dimulai ketika Dee Lestari mendapatkan pencerahan mengenai spiritualitas. Pencerahan ini membuatnya bertanya mengenai berbagai hal baik berupa pertanyaan esensial dan eksistensi manusia. Pertanyaan inilah yang ingin ia jawab sendiri dalam kemasan fiksi melalui serial Supernova. Hal ini sesuai dengan pernyataan Csikszentmihaly (1996) bahwa pribadi kreatif memiliki ide yang cerdas dan unik, tetapi pada saat yang sama mereka juga naif. Hanya saja, kemasan fiksi yang ingin ia tampilkan bukan hanya sekadar imajinasi, namun berbagai aspek ilmu pengetahuan dan spiritualitas. Oleh karena itu, riset baginya merupakan hal utama dalam pengumpulan informasi ide serial Supernova. Riset dibutuhkan agar ia menjadi yakin tentang apa yang ditulisnya. Ia menyakini jika dirinya sendiri percaya, maka pembaca pun akan percaya apa yang ditulisnya.

Tahapan yang selanjutnya dilalui setelah tahapan persiapan adalah tahapan inkubasi. Pada tahapan ini berbagai kombinasi ide yang ada dalam tahapan persiapan bermunculan, namun hanya ide yang dianggap sesuai yang akan digunakan oleh pengarang (Wallas, 1970: 93). Pada tahapan ini, pengarang akan mengendapkan ide yang telah ada dalam pemikirannya sebelum akhirnya menuliskan ide yang menjadi gambaran pengarang. Dee Lestari menyatakan dibutuhkan waktu berbulan-bulan, termasuk masa riset, untuk mengendapkan dan memetakan ide-ide cerita yang akan dituliskannya. Pada 
masa ini, ia akan memetakan berbagai ide awal dan hasil informasi, perenungan, imajinasi, dan pengalaman pada tahapan sebelumnya. Tidak sulit baginya melalui tahapan ini, karena dalam masa ini segala bahan mentah terangkum dalam peta konsep untuk memetakan jalan cerita dalam serial Supernova.

Tahapan iluminasi merupakan tahapan ketika pengarang mulai menuliskan karyanya, dalam tahapan ini terjadi "flash" atau katarsis dalam diri pengarang, segala ide yang sebelumnya abstrak dalam pikiran pengarang menjadi jelas dan terang (Wallas, 1970: 94). Hal ini pun terjadi pada Dee Lestari dalam menulis serial Supernova. Ia menyatakan bahwa konsep awal serial Supernova adalah trilogi bukan heksalogi. Supernova: KPBJ merupakan serial pertama, sedangkan pengenalan tokoh Bodhi, Elektra, Zarah dan Alfa merupakan serial kedua dan Supernova: IEP merupakan serial penutup Supernova. Konsep serial dinyatakannya merupakan konsep awal ketika ia menulis manuskrip Supernova pada tahun 2001.

Tahapan terakhir dalam proses kreatif adalah tahapan verifikasi. Pada tahapan ini, pengarang akan mengambil jarak dengan karya yang dibuatnya. Jarak yang diambil pengarang untuk melakukan proses pengembangan ide, penyuntingan, modifikasi, bahkan mengevalusi hasil karyanya secara kritis (Jabrohim, dkk, 2003: 81). Dee Lestari menyatakan proses ini merupakan proses penting dalam penulisan karyanya. Ia mengambil jarak dengan apa yang baru saja dikerjakan. Jarak antara dirinya dengan karyanya dilakukan untuk memberikan penilaian secara jernih terhadap karyanya. Ia mengaku bahwa sebelum memberikannya kepada editor, keluarga atau teman, seringkali ia melakukan self-editing. Hal ini dilakukan untuk memberikan efek arus bolak balik terhadap apa yang dituliskannya dengan maksud yang ingin ia sampaikan ketika menulis karya tersebut. Proses selanjutnya adalah beta reading dan brainstorming dengan beberapa orang termasuk editor.

Faktor-Faktor yang Memengaruhi Dee Lestari dalam Menulis Serial Supernova

Proses kreatif pengarang adalah semua hal yang mencakup pergulatan dalam diri dan luar diri pengarangnya. Berdasarkan pernyataan tersebut diketahui bahwa faktor-faktor yang memengaruhi proses kreatif terbagi menjadi dua bagian yakni secara internal dan eksternal. Secara internal, terbagi atas; 1) suasana hati, 2) pengalaman hidup, 3) imajinasi, dan 4) intuisi.

Faktor internal pertama adalah suasana hati. Suasana hati pengarang dan proses kreatif berkaitan sangat erat. Berdasarkan hasil penelitian oleh Pourjalali, dkk. (2009: 32), memiliki suasana hati yang kurang baik dapat menjadikan seseorang menjadi lebih kreatif. Namun, bagi Dee Lestari, suasana hati buruk tidak sepenuhnya memengaruhi proses kreatifnya. Dee Lestari tidak lagi bergantung pada suasana hati saat menulis, namun lebih pada komitmen untuk menyelesaikan karya yang ia buat. Hanya saja, ia lebih senang menulis tanpa adanya distraksi.

Faktor internal kedua adalah pengalaman hidup. Setiap pengarang memiliki riwayat hidup yang berbeda-beda, riwayat hidup dan pengalaman hidup yang berbeda-beda inilah yang membawa kekhasan sendiri pada setiap karya yang mereka buat. Navis (1982: 60) menyatakan pengalaman hidup yang pahit dan kesulitan hidup, kemiskinan, dan penderitaan yang menimbulkan kesadarannya dalam menulis. Hal senada pula dinyatakan Ismail bahwa bahan tulisannya adalah berbagai peristiwa dalam kehidupannya (Sayuti, 2005: 9).

Pengalaman hidup Dee Lestari yang memengaruhi dalam menulis sejak berumur tujuh belas tahun tertarik dengan berbagai pertanyaan esensial. Pertanyaan-pertanyaan tersebut akhirnya mendapatkan perhatiannya ketika ia membaca sebuah buku Conversation with God karya Neale Donald Walsch. Pencerahan ini mengubah cara pandangnya dalam berbagai hal dan menunaikan cita-cita masa kecilnya untuk memiliki sebuah buku. Kegelisahan mengenai pencarian jati diri ini juga menjadi topik-topik utama dalam karya Dee Lestari, bukan hanya serial Supernova, namun beberapa karyanya yang lain seperti Perahu Kertas, Madre, Filosofi Kopi, dan Rectoverso. Khususnya dalam serial Supernova, ia merasa dapat menemukan Tuhan.

Faktor internal selanjutnya adalah imajinasi. Karya sastra merupakan perpaduan antara imajinasi dan kontemplasi, pengalaman, dan pengamatan bahkan penelitian (Ratna, 2010: 
321). Berdasarkan pendapat Ratna tersebut, diketahui bahwa imajinasi merupakan salah satu faktor penting dalam berproses kreatif. Hal ini senada dengan yang dinyatakan Kuntowijoyo (Anwar, 2005: 5) bahwa dalam menulis karya satra ia menetapkan prinsip "three in one", yakni strukturisasi pengalaman, strukturisasi imajinasi, dan strukturisasi nilai yang ingin disampaikan. Bagi Dee Lestari, imajinasi ikut berperan aktif dalam proses kreatifnya. Hal ini dapat dilihat dari berbagai konsep mengenai Peretas, Infiltran, Umbra, Sarvara yang dinyatakannya terinspirasi dari konsep Bodhisatva. Selain konsep tersebut pemilihan latar Bukit Jambul dalam Supernova: Partikel, juga merupakan hasil imajinasi Dee Lestari.

Faktor internal terakhir adalah intuisi. Salah satu faktor yang memengaruhi proses kreatif pengarang adalah intuisi. Intuisi merupakan kemampuan memahami sesuatu tanpa dipikirkan, dengan kata lain, berdasarkan gerak atau bisikan hati. Intuisi dalam diri Dee Lestari ketika berproses kreatif terlihat dalam keputusannya untuk membuat novel serial. Pada saat menerbitkan Supernova: KPBJ, ia merasa bahwa novel ini hanyalah bagian kecil dari apa yang ingin ia bagikan kepada pembaca, sehingga dalam cetakan pertama Supernova: KPBJ, kalimat terakhir dalam buku tersebut adalah The Beginning. Selain hal tersebut, pemilihan judul Supernova: Intelegensi Embun Pagi sebagai serial terakhir dalam Supernova menurutnya dikarenakan intuisi. Judul Supernova: IEP sendiri diungkapkannya ke publik saat Supernova: Akar diliris tahun 2002.

Selain faktor internal, terdapat pula faktor eksternal yang memengaruhi proses kreatif pengarang yang terbagi atas; 1) jenis kelamin, 2) umur, 3) pandangan hidup, 4) latar belakang sosial dan budaya serta 5) dorongan menulis.

Faktor eksternal pertama adalah jenis kelamin. Secara tradisional, perempuan adalah sosok yang tidak independen, ia adalah milik suami ataupun anak-anaknya (Beauvoir dalam Heraty, 2000: 92). Hal ini berbeda dengan seorang pengarang laki-laki yang merupakan sosok independen, meskipun antara perempuan dan laki-laki memiliki profesi yang sama sebagai pengarang, namun terdapat perbedaan antarkualitas maupun kuantitasnya. Hal inilah yang dinyatakan oleh Arieti (1976: 315) sebagai faktor penghambat tumbuhnya kebudayaan creativogenic. Bagi Dee Lestari, sebagai seorang perempuan dan berprofesi sebagai pengarang tidak memengaruhi dirinya secara aktif berproses kreatif. Keluarganya adalah penyokong utama dalam profesinya saat ini, dukungan keluargalah yang membuatnya tetap dapat menjalankan kehidupannya sebagai seorang istri dan ibu.

Faktor ekternal kedua adalah umur. Umur secara tidak langsung memengaruhi proses kreatif seorang pengarang. Bagi Dee Lestari, umur memengaruhi dirinya dalam berkarya. Hal ini dinyatakannya secara tersirat karena baginya Supernova adalah jurnal spiritualnya dan ia merasa tumbuh dan berkembang dengan serial ini selama lima belas tahun.

Faktor eksternal lainnya adalah pandangan hidup. Karya sastra dan masyarakat merupakan struktur yang berhubungan. Hubungan tersebut dimediasi oleh pandangan pengarang. Seorang pengarang akan mencipta, mengumpulkan, dan mengembangkan tokoh-tokoh ceritanya, membagi peran antara mereka, yang secara sadar maupun tidak sadar, ciptaannya juga akan dipengaruhi oleh pandangan hidup pengarang tersebut (Faruk, 2012: 163). Hal ini ikut memengaruhi proses kreatif Dee Lestari dalam menulis serial Supernova. Gambaran mengenai pandangan hidup Dee Lestari yang terdapat dalam serial Supernova: KPBJ terlihat dalam penggambaran pasangan homoseksual pada tokoh Ruben dan Dimas dan berbagai aspek ilmiah dalam serial tersebut. Gambaran pasangan homoseksual dalam tokoh Reuben dan Dimas semata-mata merupakan pandangan divergen Dee Lestari terhadap pasangan heteroseksual tokoh Rana dan Arwin. Pasangan Rana dan Arwin digambarkan memiliki berbagai persoalan sehingga Rana memilih untuk menduakan Arwin dengan Ferre. Pasangan homoseksual dalam tokoh Reuben dan Dimas memiliki hubungan yang terlihat lebih 'normal' dibandingkan dengan pasangan heteroseksual Rana dan Arwin.

Faktor eksternal keempat adalam latar belakang sosial dan budaya. Pengarang sebagai salah satu dari anggota masyarakat, senantiasa membuat sebuah karya sastra yang mengandung nilai-nilai sosial dan budaya. Hal ini merupakan 
salah satu faktor yang secara sadar maupun tidak sadar dipantulkan oleh pengarang melalui karyanya. Persoalan lingkungan merupakan salah satu latar belakang sosial yang memengaruhi Dee Lestari dalam berkarya. Persoalan lingkungan ini dinyatakannya sebagai salah satu cara untuk menyatukan manusia diseluruh dunia mengenai pentingnya menjaga lingkungan. Isu lingkungan inilah yang diungkapkannya dalam serial Supernova: Partikel dengan tokoh utama Zarah.

Faktor eksternal terakhir adalah dorongan menulis. Setiap pengarang memiliki dorongan menulis yang berbeda-beda, dengan adanya dorongan menulis ini pengarang mampu menyelesaikan karyanya. Dorongan menulis dalam diri Dee Lestari terbentuk dari masih kecil, saat berumur sembilan tahun ia memiliki impian untuk mempunyai sebuah buku yang terpajang di rak toko buku. Namun, dorongan utama yang membuat Dee Lestari mampu menyelesaikan karyanya adalah komitmen dan disiplin. Dua hal ini yang membuatnya dapat menyelesaikan serial Supernova, walaupun dalam proses penulisan serial Supernova sempat terhenti delapan tahun, yakni sejak diterbitkannya Supernova: Petir tahun 2003 dan delapan tahun kemudian Supernova: Partikel akhirnya terbit. Ia menyatakan bahwa tertundanya menerbitkan serial Supernova setelah Petir karena peralihan peran sebagai seorang istri dan ibu. Selain hal tersebut, waktunya juga tersita dengan mengerjakan berbagai karya kreatif lainnya seperti menulis Filosofi Kopi, Rectoverso, Madre, dan Perahu Kertas. Karya lainnya dipilih oleh Dee Lestari karena saat itu ia merasa belum mampu menulis secara maraton serial Supernova, sehingga lebih memilih untuk berkarya dengan konsep tulisan yang lebih pendek.

\section{Wujud Proses Kreatif Dee Lestari dalam Menulis Serial Supernova}

Setiap pengarang memiliki kebebasan dalam berproses kreatif, hal inilah yang membedakan proses kreatif pengarang yang satu dengan yang lainnya. Kebebasan ini yang dimiliki Dee Lestari dalam berproses kreatif, yakni dengan memilih tema, alur, latar, dan penokohan sebagai sebuah fakta cerita. Kebebasan dalam memilih keempat elemen tersebut didasarkan bahwa secara faktual, elemen tersebut dapat dibayangkan peristiwa dan eksistensinya dalam sebuah karya sastra. Perwujudan mengenai keempat elemen, yakni 1) tema, 2) latar, 3) alur, dan 4) penokohan ini yang digambarkan Dee Lestari dalam berproses kreatif.

Wujud proses kreatif pertama, tergambar dalam tema. Tema adalah dasar cerita, gagasan dasar umum, sebuah karya cerpen atau novel. Tema merupakan elemen yang relevan dengan setiap peristiwa dan detail sebuah cerita (Stanton, 2012: 37). Pemilihan tema ini didasarkan Dee Lestari terhadap pencerahan kecil atau epifani yang didapatkannya pada tahun 1999. Wujud proses kreatif Dee Lestari dalam pemilihan tema spiritualitas terlihat dalam konsep Bodhisatva. Konsep inilah yang melahirkan istilah Peretas, Infiltran, Sarvara, Umbra, serta misi mereka di Bumi.

Wujud proses kreatif kedua, tergambar dalam latar. Latar atau setting adalah segala keterangan, petunjuk, pengacuan yang berkaitan dengan waktu, ruang, dan suasana terjadinya peristiwa dalam suatu karya sastra (Sudjiman 1992: 44). Dalam konteks pemilihan latar dalam serial Supernova, Dee Lestari menyatakan didasarkan pada kebutuhan cerita. Hal ini ditunjukkan dalam berbagai serial Supernova yang memiliki latar yang berbeda-beda. Dalam serial Supernova pertama, Kesatria, Putri, dan Bintang Jatuh (KPBJ), latar tempat dalam serial tersebut didominasi di Indonesia. Berbeda halnya dengan latar tempat dan situasi tokoh Bodhi dalam Supernova: Akar. Tokoh Bodhi digambarkan sebagai seseorang yang tercerabut dari akarnya. Ia kehilangan jati dirinya dan teralienisasi karena keadaan fisiknya yang anomali. Latar tempat dan suasana dalam serial ini didominasi oleh perjalanan Bodhi ke berbagai negara di wilayah ASEAN.

Latar tempat dan suasana pun dirasakan berbeda dalam serial ketiga Supernova: Petir. Novel ini menggambarkan tokoh utama yang bernama Elektra hidup sebatang kara, yatim piatu, dan tanpa pekerjaan. Elektra digambarkan sebagai seseorang yang tidak punya percaya diri dan pemalas, sifatnya ini membuat dirinya kehilangan jati dirinya. Latar tempat dalam serial ini pun didominasi oleh rumah Elektra yang berdomisili di Bandung. Dalam serial Supernova: 
Partikel latar tempat didominasi oleh berbagai tempat seperti di Bogor, Tanjung Puting, hingga London. Berbagai lokasi tersebut dipilih Dee untuk memenuhi kebutuhan cerita mengenai perjalanan diri Zarah mencari ayahnya dan profesinya sebagai fotografer alam yang mengharuskannya berkeliling ke berbagai tempat. Latar tempat yang mendominasi serial Supernova: Gelombang adalah Sianjur Mula-Mula dan Amerika. Lokasi tersebut dipilih sesuai dengan kebutuhan cerita, serial ini menggambar tokoh utama bernama Alfa keturunan Batak. Pelarian dari mimpi kelabunya membawanya hingga ke Amerika dan berkarir di Wallstreet.

Latar tempat dalam serial Supernova: IEP didominasi oleh latar-latar yang terdapat dalam serial sebelumnya, seperti Elektra Pop di Bandung yang terdapat dalam serial Supernova: Petir, Bukit Jambul dan rumah Zarah di Batu Luhur yang terdapat dalam serial Supernova: Partikel hingga Sianjur Mula-Mula dalam serial Supernova: Gelombang. Pemilihan berbagai latar tempat tersebut tidak lain untuk menjalin keterkaitan antara serial terakhir ini dengan serial Supernova sebelumnya. Wujud proses kreatif Dee Lestari dalam pemilihan latar tempat terlihat dari pemilihan latar berbagai wilayah di Asean dalam serial Supernova: Akar yang menggambarkan jiwa petualangan Dee. Pemilihan latar kota Bandung dalam serial Supernova: Petir, yang mewakili tempat tinggal Dee dan pemilihan latar Sianjur Mula-Mula dalam serial Supernova: Gelombang, yang mewakili dirinya sebagai keturunan Batak.

Wujud proses kreatif selanjutnya tergambar dalam alur. Kehadiran berbagai unsur intrinsik dalam karya sastra dimaksudkan untuk membangun cerita, salah satunya adalah alur. Tahapan alur yang dibentuk oleh satuan-satuan peristiwa dalam setiap tahapan tersebut, terdapat unsur pembangun karya sastra lainnya seperti tokoh-tokoh dengan perwatakan tertentu, latar, tema, serta unsur-unsur pembangun karya sastra lainnya, melalui pemahaman alur yang baik, pembaca sekaligus memahami penokohan, perwatakan, maupun latar cerita (Nurgiyantoro, 2012: 114). Penyusunan alur dalam serial Supernova oleh Dee Lestari, didasarkan pada struktur tiga babak yang terdiri atas pembuka, konflik, dan penyelesaian. Struktur tiga babak inilah yang digunakannya dalam menyusun pemetaan cerita serial Supernova.

Penyusunan tahapan alur serial Supernova mengikuti kebutuhan cerita dan teknik pemetaan cerita yang digunakan Dee Lestari dalam menyusun tahapan alur. Gambaran mengenai tahapan alur dalam Supernova didominasi oleh tahapan alur maju mundur, hal ini terlihat dalam serial Supernova: Akar, Petir, Partikel, dan Gelombang yang menggambarkan kehidupan masing-masing tokoh utama dengan menceritakan kembali kisah hidup mereka. Tidak seperti serial lainnya, dalam Supernova: $K P B J$ dan IEP, tahapan alur didominasi oleh penggunaan alur maju untuk mempertegas adegan yang bermuatan konflik, klimaks, antiklimaks hingga penyelesaian. Wujud proses kreatif Dee Lestari dalam penggambaran alur terlihat dalam kompleksitas pengembangan alur yang diwakili konsep awal serial Supernova sebagai serial trilogi menjadi heksalogi.

Wujud proses kreatif terakhir tergambar dalam penokohan. Penokohan sebagai salah satu unsur dalam karya sastra, menggambarkan berbagai tokoh-tokoh rekaan. Tokoh dalam sebuah cerita rekaan dibuat menyakinkan apabila pengarang mampu melengkapi diri dengan pengetahuan yang luas dan dalam mengenai sifat tabiat manusia, serta kebiasaan bertindak dan berujar di dalam lingkungan masyarakat yang hendak digunakannya sebagai latar (Sudjiman, 1992: 27). Hal inilah yang digunakan Dee Lestari dalam menggambarkan setiap tokoh dalam karyanya.

Dalam serial Supernova, Dee menyatakan bahwa setiap tokoh dalam karyanya adalah kain perca dari berbagai sumber seperti imajinasi, mengamati orang lain, bahkan dirinya sendiri. Setiap tokoh utama pada serial Supernova merupakan cerminan bagi tokoh di serial berikutnya, seperti pada serial Supernova: Akar, tokoh Bodhi merupakan komplementer tokoh Elektra dalam serial Supernova: Petir. Bodhi melambangkan dunia bawah, sedangkan Elektra melambangkan dunia atas yang berkaitan dengan urusan akhirat. Tokoh Zarah dalam Supernova: Partikel merupakan simbol dari bumi sedangkan tokoh Alfa dalam Supernova: Gelombang merupakan simbol dari gelombang kesadaran. Kedua tokoh tersebut memiliki per- 
samaan karena merupakan gambaran komponen gelombang dalam sains.

Dalam pemilihan nama tokoh, Dee Lestari menentukan dari makna simbol yang terdapat dalam tokoh tersebut. Tokoh Bodhi dalam serial Supernova: Akar namanya terinspirasi dari sebuah pohon bernama Bodhi. Pemilihan nama tersebut didasarkan pada simbol Bodhi yang erat kaitanya dengan unsur duniawi, keterikatan dirinya dengan asal-usulnya yang dimaknai oleh Dee sebagai akar. Nama Elektra dalam serial $\mathrm{Su}$ pernova: Petir berkaitan dengan kekuatan yang dimiliki Elektra yang berasal dari aliran listrik. Dee Lestari menyukai keberagaman, sehingga ia memilih nama Wijaya untuk menegaskan Elektra sebagai orang Indonesia keturunan Tionghoa. Pemilihan nama Zarah dalam Supernova: Partikel, didasarkan pada makna Zarah dalam bahasa Arab, yang juga berarti partikel. Pemilihan nama yang berasal dari bahasa Arab ini mengilhaminya untuk menggambarkan Zarah sebagai perempuan keturunan arab. Nama Alfa dalam serial Supernova: Gelombang, terinspirasi dari berbagai macam gelombang dalam arti ilmiah. Wujud proses kreatif Dee dalam penokohan tergambar dalam berbagai tokoh utama yang terdapat dalam serial Supernova. Seperti dalam tokoh Dimas dan Rueben dalam Supernova: KPBJ yang mewakili pertanyaan eksensial dalam diri Dee, sisi humoris Dee dalam diri tokoh Elektra dalam Supernova: Petir, dan kepedulian Dee terhadap lingkungan yang terwakili dalam diri tokoh Zarah sebagai seorang pecinta lingkungan yang juga berprofesi sebagai seorang fotografer alam.

\section{Teknik Penceritaan Dee Lestari dalam Menu- lis Serial Supernova}

Pengarang sudah pasti pencerita, tetapi pencerita belum tentu pengarang. Tokoh utama dapat dikatakan sebagai pencerita dengan menceritakan dirinya sendiri dan tokoh-tokoh lain yang ada dalam cerita tersebut. Pencerita juga dapat berupa tokoh bawahan yang dekat dengan tokoh utama (Sudjiman, 1992: 60). Pencerita berupa pencerita akuan dan diaan. Pencerita akuan merupakan tokoh cerita yang berkisah tentang dirinya sendiri dan tentang tokoh-tokoh lainnya, sedangkan pencerita diaan yaitu pencerita yang bukan merupakan tokoh di dalam cerita
(Luxemburg, dkk, 1989: 118). Dalam serial Supernova, pencerita didominasi oleh pencerita akuan yang terdapat dalam serial Supernova: Akar, Petir, Partikel dan Gelombang, sedangkan dua serial lainnya yakni Supernova: KPBJ dan $I E P$ menggunakan penceritaan diaan.

Gambaran kekhasan penulisan Dee Lestari terlihat dari berbagai teknik penceritaan yang digunakannya dalam menulis sebuah karya, yakni dengan menggabungkan berbagai teknik dalam setiap karyanya, seperti, 1) teknik pemandangan, 2) teknik adegan, 3) teknik montase, 4) teknik kolase, dan 5) teknik asosiasi, seperti yang dijabarkan sebagai berikut.

Teknik pertama adalah teknik pemandangan. Teknik pemandangan adalah teknik yang digunakan pencerita dengan menyajikan latar fiksi secara luas dan umum, tokoh digambarkan secara umum dan jangka waktu yang panjang dikisahkan dengan satu kalimat atau di dalam satu paragraf(Sudjiman, 1992: 91). Gambaran mengenai teknik pemandangan dalam serial Supernova terlihat dalam penceritaan tokoh utama mengenai latar tempat, waktu maupun suasana yang terdapat dalam masing-masing serial. Penyusunan latar dengan menggunakan teknik pemandangan juga digunakan Dee Lestari untuk membawa para pembaca seolah-olah ikut terbawa dalam suasana tempat dan waktu yang digambarkan dalam serial Supernova. Hal ini digunakan untuk membuat pembaca terhanyut dalam cerita Supernova dengan mengikutsertakan imajinasi pembaca ketika membacanya.

Teknik penceritaan kedua adalah teknik adegan, teknik adegan adalah teknik penceritaan yang dilakukan oleh pencerita dengan menyajikan sebuah cerita seperti adegan dari sebuah film, sehingga pembaca seolah-olah sangat dekat dengan kejadian dan melihat langsung peristiwa yang disajikan (Sudjiman, 1992: 92). Gambaran mengenai teknik adegan dalam serial Supernova terlihat dalam berbagai konflik yang memaksa tokohnya untuk menemukan jalan keluar.

Teknik penceritaan selanjutnya adalah teknik montase. Teknik montase digunakan untuk menciptakan suasana melalui serangkaian impresi dan observasi yang diatur secara tepat (Sudjiman, 1992: 95). Gambaran mengenai teknik montase dalam serial Supernova, terlihat dari petunjuk mengenai hubungan antara 
berbagai tokoh dalam serial Supernova yang berhubungan dengan serial lainnya. Seperti terlihat dalam serial Supernova: Akar, antara Kell dan Star yang digambarkan saling tolakmenolak. Hal ini dijabarkan dalam Supernova: Gelombang oleh dr. Kalden mengenai reaksi Sarvara dan Infiltran yang bila bertemu akan saling tolak- menolak. Dari penjelasan dr. Kalden ini pun diketahui bahwa baik Sarvara maupun Infiltran tidak dapat mati, mereka akan terlahir kembali baik dalam wujud yang sama seperti sebelumnya atau berbeda. Hal ini tergambar ketika Alfa bertemu dengan Kell dalam perjalanan pulangnya ke Jakarta, sedangkan dalam Supernova: Akar, Kell digambarkan telah tewas karena menginjak ranjau darat. Dialog-dialog yang terdapat dalam serial Supernova pun disusun Dee Lestari sebagai gambaran mengenai petunjuk misi besar setiap tokoh yang dijabarkan dalam serial terakhir yakni Supernova: IEP.

Teknik penceritaan keempat adalah teknik kolase. Teknik kolase merupakan teknik penceritaan yang sarat dengan kutipan dari karya sastra lain, dengan alusi, atau ungkapan asing, yang biasanya dianggap tidak ada hubungan satu dengan yang lain. Peristiwa yang terkadang terpotong-potong oleh pencantuman hal-hal dari kehidupan yang sebenarnya yang umum dikenal, seperti lagu pop, teks iklan, dan guntingan koran (Sudjiman, 1992: 98). Teknik ini digunakan Dee Lestari untuk menerangkan berbagai latar situasi, waktu, dan tempat berbagai tokoh dalam serial Supernova menempuh berbagai konflik dalam pergulatan batinnya. Gambaran mengenai teknik kolase dalam serial Supernova terlihat dari penyebutan film James Bond, lagu Eye in The Sky dan lagu No Woman No Cry.

Teknik penceritaan terakhir adalah teknik asosiasi. Teknik asosiasi merupakan teknik penceritaan melalui serangkaian episode atau peristiwa yang nampaknya tidak berkaitan dengan cerita inti (Sudjiman, 1992: 99). Gambaran mengenai teknik asosiasi dalam serial Supernova terlihat dari berbagai tokoh dan dialog yang digunakan Dee Lestari untuk menjalin benang merah antara serial yang satu dengan yang lainnya. Supernova sebagai novel dengan tema spiritualitas, setiap tokoh utama dalam serial ini merupakan reinkarnasi dari Peretas sebelum lahir di dunia, amnesia inilah yang akan menolong mereka dari radar Sarvara. Dee Lestari menggambarkan amnesia tokoh utama dengan menyertakan berbagai dialog yang secara kausal seperti tidak berkaitan namun menunjukkan keterhubungan.

\section{SIMPULAN}

Tahapan proses kreatif Dee Lestari dalam menulis serial Supernova melalui empat tahapan, yakni tahapan persiapan, inkubasi, iluminasi dan verifikasi. Tahapan persiapan dimulai ketika pengamatan, pengalaman, bahan riset dan imajinasi terakumulasi. Akumulasi ini akan memunculkan berbagai pertanyaan mengenai spiritualitas dalam diri Dee Lestari. Tahapan selanjutnya adalah inkubasi. Dalam tahapan ini, diperlukan jangka waktu berbulan-bulan hingga satu tahun, termasuk masa riset, dalam proses pengendapan, sebelum ia mulai menulis sebuah karya. Tahapan iluminasi terjadi ketika Dee Lestari mengalami katarsis pada saat proses menulis berlangsung. Tahapan terakhir, tahapan verifikasi dimulai ketika proses modifikasi dan penyuntingan dilakukan oleh diri Dee sendiri. Ia akan memberikan jarak antara dirinya dan karyanya serta mengevaluasi karya tersebut secara teliti. Setelah dirasa cukup, proses selanjutnya adalah beta reading dan brainstorming.

Faktor-faktor yang memengaruhi proses kreatif Dee Lestari dalam menulis serial Supernova terbagi menjadi dua bagian yakni secara internal dan eksternal. Berdasarkan hasil penelitian diketahui bahwa baik faktor internal dan eksternal memengaruhi proses kreatif Dee Lestari. Hal ini terlihat dari komitmen dan disiplin Dee Lestari dalam menyelesaikan karyanya bukan hanya karena suasana hati tertentu. Pengalaman hidup dan imajinasi juga memengaruhinya dalam memilih berbagai elemen yang menjadi topik penulisan pada serial Supernova, seperti istilah Peretas, Infiltran, Sarvara, hingga pemilihan latar Bukit Jambul. Intuisi dan spontanitas digunakannya sebagai bentuk dari katarsis saat menulis sebuah karya. Secara faktor eksternal, perbedaan jenis kelamin dan rentangan umur tidak menghalangi proses kreatif Dee Lestari, karena baginya menulis adalah suatu kebutuhan. Pandangan hidup, latar belakang sosial, dan budaya serta dorongan menulislah yang memberikan sumbangan 
terbesar dalam menumbuhkan kepercayaan dirinya dalam menulis, menyertakan berbagai topik yang menarik minatnya dalam menulis hingga menyatakan pandangan divergen atas suatu persoalan.

Wujud proses kreatif Dee Lestari dalam menulis serial Supernova terlihat pada empat elemen yakni tema, alur, latar, dan penokohan. Wujud proses kreatif Dee dalam pemilihan tema spiritualitas terlihat dalam konsep Bodhisatva yang melekat dalam serial Supernova. Konsep inilah yang melahirkan istilah Peretas, Infiltran, Sarvara, Umbra, serta misi mereka di Bumi. Dalam latar, perwujudan proses kreatif Dee terlihat dalam pemilihan Bandung dan Sianjur Mula-Mula sebagai latar tempat dalam serial Supernova, walaupun terdapat tempat-tempat tertentu hasil imajinasi Dee Lestari, seperti Bukit Jambul. Wujud proses kreatif Dee dalam alur terlihat dalam kompleksitas cerita, sehingga konsep awal Supernova: Akar, yang sebelumnya direncanakan hanya satu bab menjadi satu buku. Hal ini tentu memengaruhi tahapan alur serial lainnya, hingga serial Supernova yang sebelumnya merupakan serial trilogi menjadi heksalogi. Wujud proses kreatif Dee dalam penokohan terlihat dari tokoh Dimas dan Reuben yang digambarkannya dalam Supernova: KPBJ. Tokoh tersebut mencerminkan pertanyaan-pertanyaan esensial yang terdapat dalam dirinya. Selain Reuben dan Dimas, tokoh Zarah mencerminkan kepeduliannya terhadap lingkungan dalam Supernova: Partikel, tokoh Elektra menggambarkan sisi humorisnya, sedangkan tokoh Bodhi menggambarkan sisi petualangannya.

Teknik penceritaan Dee Lestari dalam menulis serial Supernova tampak pada teknik yang digunakan. Teknik pemandangan digunakannya untuk membangkitkan imajinasi pembaca sehingga seolah-olah merasakan tempat yang digambarkan. Teknik pemandangan ini berbeda penggunaannya dengan teknik adegan yang menyertakan berbagai dialog, karena dialog esensinya adalah sebuah konflik. Teknik montase, kolase, dan asosiasi digunakannya untuk menjelaskan berbagai hal dalam serial yang satu dengan yang lainnya, seperti konsep Peretas, Infiltran, dan Sarvara. Penggunaan teknik montase digunakan untuk memberikan penjelasan mengenai tugas sang tokoh, teknik kolase digunakan untuk mencatut berbagai hal yang terdapat dalam kehidupan sehari-hari, seperti potongan lagu dan film sebagai gambaran realitas dalam serial Supernova, sedangkan teknik asosiasi digunakan untuk menghubungkan keterkaitan antara serial pertama hingga serial terakhir Supernova. Penggunaan kelima teknik penceritaan ini didasarkan pada kebutuhan cerita dan masing-masing teknik dapat digunakan secara bergantian. Dari penggunaan kelima teknik tersebut diketahui bahwa kekhasan tulisan Dee Lestari tampak dalam pemilihan kata-kata yang bermetafora, namun dijabarkan dengan bahasa yang lugas dan jernih. Setiap pilihan kata yang digunakannya memunculkan beberapa istilahistilah ilmiah yang dipadupadankan dengan metafora. Hal ini berkaitan dengan latar belakang Dee Lestari yang sebelumnya menjadi seorang penyanyi dan penulis lagu, sehingga baginya, kalimat merupakan sebuah musik yang memiliki ketukan, irama, dan melodi.

\section{DAFTAR PUSTAKA}

Abrams, M.H. 1971. The Mirror and the Lamp: Romantics Theory and the Critical Tradition. New York: Oxford Univversity Press.

Anwar, W. 2005. Kuntowijoyo: Karya dan Dunianya. Jakarta: Grasindo.

Arieti, S. 1976. Creativity: the Magical Synthesis. New York: Basic Books.

Beauvoir, S. 2000. Nasib Pengarang Perempuan (Diterjemahkan oleh Haniah). dalam Toeti Heraty (ed). Hidup matinya sang pengarang. Hlm. 126-136. Jakarta: Yayasan Obor.

Csikszentmihalyi, M. 1996. Creativity: Flow and the Psychology of Discovery and Invention. New York: HarperCollins.

Faruk. 2012. Metode Penelitian Sastra: Sebuah Penjelajahan Awal. Yogyakarta: Pustaka Pelajar.

Jabrohim, Anwar, \& Sayuti, S. A.. 2003. Cara Menulis Kreatif. Yogyakarta: Pustaka Pelajar.

Junus, U. (1985). Resepsi Sastra. Jakarta: Gramedia.

Luxemburg, dkk. (1989). Tentang Sastra (diterjemahkan oleh Akhadiati Ikram). Jakarta: Intermasa. 
Mahayana, M. S. (2007). Ekstrinsiksikalitas Sastra Indonesia. Jakarta: Raja Grafindo Persada.

Mabruri, Z. K.\& Sayuti, S. A. 2015. Potret sosial dalam sepuluh sajak remy sylado dan relevansinya dengan pembelajaran sastra di sma. LingTera, 2 (1), 101 - 110. Available at: <https:// journal.uny.ac.id/index.php/ljtp/article/ view/5412/4708>.

Navis, A.A. 1982. Proses Penciptaan, dalam Pamusuk Eneste (ed). Proses kreatif: Mengapa dan Bagaimana Saya Mengarang jilid 1,hlm. 51-73. Jakarta: Gramedia.

Nurgiyantoro, B. 2012. Teori Pengkajian Fiksi. Yogyakarta: UGM Press.

Pourjalali, S., dkk. 2009. The Creative Writer, Dysphoric Rumination and Locus of Control. Dalam Scott B. Kaufman \& James C. Kaufman (ed.). The psychology of Creative writing, hlm. 23-40. New York: Cambridge University Press.
Ratna, N. K. 2010. Metodologi Penelitian: Kajian Budaya dan Ilmu Sosial Humaniora pada Umumnya. Yogyakarta: Pustaka Pelajar.

Sayuti, S. A. 2005. Taufiq Ismail: Karya dan Dunianya. Jakarta: Grasindo.

Semi, M. A. 1993. Mencari Pendekatan Pengajaran Sastra yang Relevan. dalam Sastra. Volume 04 Agustus.

Sudjiman, P. 1992. Memahami Cerita Rekaan. Jakarta: Pustaka Jaya.

Stanton, R. 2012. Teori Fiksi Robert Stanton (diterjemahkan Sugihastuti \& Rossi Abi Al Irsyad). Yogyakarta: Pustaka Pelajar.

Wallas, G. 1970. The Art of Thought. Dalam P. E. Vernon (Ed). Creativity, hlm. 91-97. Victoria: Penguin Books Australia. 